P. van Beynen, R. Brinkmann, and K. van Beynen - A sustainability index for karst environments. Journal of Cave and Karst Studies, v. 74, no. 2, p. 221-234. DOI: $10.4311 / 2011 \mathrm{SS} 0217$

\title{
A SUSTAINABILITY INDEX FOR KARST ENVIRONMENTS
}

\author{
Philip van Beynen ${ }^{* *}$, Robert BrinkmanN², AND Kaya van Beynen³
}

\begin{abstract}
With growing populations and ever increasing pressure on resources, the need to live sustainably with our environment has increased in significance. When considering such anthropogenic pressures, karst landscapes are as vulnerable, if not more so, than any other environment. Such vulnerability arises from the rapid transit times of percolating water, the poor filtering ability of carbonate bedrock, and the highly specialized biota of subterranean karst. The Karst Sustainability Index (KSI) was created as a standardized metric of sustainable development practices in karst settings. The KSI uses predetermined targets to ascertain the overall sustainability of a karst region. Indicators are designed to incorporate common measures of sustainability for the three domains of social, environmental, and economic resource use. Benchmarking the current state of karst environments allows the comparison of sustainability practices temporally and spatially to highlight areas where remedial policies or actions are needed. This is the first index to incorporate the emerging field of environmental sustainability with karst landscape assessment. To test the applicability of the KSI, a study was undertaken in the Tampa Bay Metropolitan Area, which encompasses four counties that are entirely karst. The TBMA was found to be progressing towards the sustainable management of karst resources, and the KSI provided a robust measure of sustainability.
\end{abstract}

\section{INTRODUCTION}

Karst environments are settings of predominantly carbonate rocks that have been subject to dissolution over time, resulting in a unique physical landscape characterized by sinkholes, disappearing streams, dry valleys, and caves (Ford and Williams, 2007). Rapid flow of water from the surface into the carbonate rocks and the aquifers they contain is a typical feature of karst, but also one that is problematic for resource managers (Fleury, 2009). Subterranean cavities are renowned for their fragile ecosystems, and many are sites of endangered species, with some species endemic to single caves (Culver and Pipan, 2009).

These unique characteristics of karst environments make them highly vulnerable to human disturbance. Activities such as agriculture, urban development, waste disposal, deforestation, and resource extraction constitute environmental pressures leading to polluted aquifers, destroyed caves, declining biodiversity, and denuded landscapes (Table 1). Aquifers can become contaminated because surface spills percolate quickly through the epikarst and plumes can expand kilometers in a single day, characteristics that make mitigation difficult. Caves are destroyed either through quarrying, construction, vandalism, or sediment influxes from deforestation. Slow degradation of these conduits can occur from misguided tourist operations. Agriculturally contaminated water, excessive water withdrawals, human visitation, and quarrying can cause cave biota to become stressed or even disappear altogether. Table 1 provides a more detailed overview of how human practices can alter karst systems. The Karst Disturbance Index created by van Beynen and Townsend (2005) uses environmental indicators to measure qualitative and quantitative human impacts on karst landscapes. It has been successfully applied in different countries by various researchers (Calò and Parise, 2006; van Beynen et al., 2007; De Waele, 2009; North et al., 2009; Day et al., 2011).

Due to increased awareness of the effects of human disturbance across many different landscapes with growing human populations, efforts have been made to reduce negative impacts and promote sustainable development. The modern sustainability movement in the West emerged from the transcendental thinkers of the nineteenth century. However, the publication Leopold's Sand County Almanac (1949) and Carson's Silent Spring (1962) brought together the philosophical value of nature with the need to change human practices to preserve the planet. With the advent of the UN's Brandt and Bruntland reports in the 1970-80s, sustainability has become a cornerstone of a more ecocentric worldview of environmental management (Dalby et al., 2009). The Brundtland report presented one of the first definitions of sustainability, characterizing it as "development that meets the needs of the present without compromising the ability of future generations to meet their own needs" (World Commission on Environment and Development, 1987). At the 1992 Rio de Janeiro UNCED Conference, discussions led to the development of environmental indices that address sustainable development. A decade later, the 2002 UN World Summit on Sustainable Development in Johannesburg further cemented the world's resolve that steps had to be taken to

\footnotetext{
* Corresponding author: vanbeyne@usf.edu

${ }^{1}$ Department of Geography, Environment and Planning, NES 107, University of South Florida, Tampa, FL 33620

${ }^{2}$ Department of Global Studies and Geography, Hofstra University, 209F Roosevelt Hall, Hofstra University, Hempstead, NY 11549

${ }^{3}$ Nelson Poynter Library, University of South Florida, St Petersburg, FL 33701
} 
Table 1. Examples of human uses of karst environments and issues arising from human use.

\begin{tabular}{|c|c|c|}
\hline Uses & Components: Subcomponents & Issue \\
\hline Quarries & Opencast: Aggregate/ore extraction & $\begin{array}{l}\text { Destruction of caves, epikarst, forests; Alteration of } \\
\text { hydrology; Groundwater pollution from tailings }\end{array}$ \\
\hline Mining & Underground: Ore extraction & Hydrology alteration; Water pollution; Surface subsidence \\
\hline \multirow[t]{2}{*}{ Agriculture } & Extensive: Grazing & $\begin{array}{l}\text { Pesticide/herbicide use; Deforestation; Fertilizers; Soil } \\
\text { compaction; Erosion from over grazing }\end{array}$ \\
\hline & Intensive: Feed lots Horticulture & $\begin{array}{l}\text { Soil compaction; Effluent runoff; Fertilizers; Pesticides/ } \\
\text { herbicides/antibiotics; Erosion; Alteration of hydrology }\end{array}$ \\
\hline Forestry & Parkland: N.A. Logging: N.A. & $\begin{array}{l}\text { Clearcutting; Alteration in hydrology; Fertilizers; Increased } \\
\text { erosion from roads and clearing; Poor management of } \\
\text { caves on land }\end{array}$ \\
\hline \multirow[t]{3}{*}{ Tourism } & Springs: Private/Public & Pollution; Overuse; Infrastructure; Clogging \\
\hline & Caves: Private/Public & $\begin{array}{l}\text { Overuse (too many visitors); Destruction (vandalism, } \\
\text { desiccation); Infrastructure (buildings, lights, paths, } \\
\text { roads) }\end{array}$ \\
\hline & Surface Features: N.A. & Removal; Infrastructure; Destruction; \\
\hline \multirow[t]{4}{*}{ Urban Landuse } & Low Density: N.A. & Increased impervious surfaces; Water pollution; Decreased \\
\hline & High Density: N.A. & forests; Changes in hydrology; Infilling of sinkholes \\
\hline & Commercial: N.A. & \\
\hline & Industrial: N.A. & \\
\hline \multirow[t]{2}{*}{ Water Use } & Withdrawals: N.A. & Over extraction \\
\hline & Dumping/Disposal: N.A. & Pollution \\
\hline
\end{tabular}

change human-environment interaction, steps that mutually recognize that development is inevitable, but must occur within a sustainable framework that ensures future access to our natural resources. At the 2005 World Summit in New York City, sustainable development was defined as incorporating three components, economic development, social development, and environmental protection (United Nations General Assembly, 2005). The exact framework for achieving sustainability has yet to be agreed upon, reflecting the conflicts between ecological conservation and resource exploitation and a lack of political will. There is a clear need to develop quantitative measures and plans that help facilitate a sustainable society (Brinkmann and Garren, 2011). Following these international efforts, a variety of environmental indices have been created to determine how nations or states incorporate sustainability measures into their societies (Table 2). Examples of these indices include State of the Environment (Briggs, 1998), Wellbeing of Nations (Prescott-Allen, 2001), the Millennium Ecosystem Assessment (Hassan et al., 2005), the Report on the Environment (US EPA, 2008), and the Heinz State of the Ecosystem report (H. John Heinz III Center for Science, 2008). Other indices that attempt to measure the impact humans have on their environment are the ecological footprint (Wackernagel and Rees, 1996), the human development index (United Nations Development Program, 2003), the water poverty index (Sullivan et al., 2003), and the water footprints of nations (Chapagain and Hoekstra, 2004). This list is by no means comprehensive, but provides some evidence of the efforts taken to promote the concept of sustainability. Sustainable development requires factoring social, environmental, and economicresource use considerations into decision-making pertaining to environment management (Kelly, 1998). All of the above approaches incorporate these factors in different ways.

To date, little work has been done on creating sustainability indices for specific environments. The Environmental Sustainability Index (World Economic Forum, 2002) is a large, comprehensive index that is applied regardless of the intricacies of environment type. Environmental sustainability indices that are landscapespecific are the Working Wetland Potential (McCartney and Houghton-Carr, 2009), Coastal Index (Shi et al., 2004), and several for agricultural and urban settings (van Dijk and Zhang, 2005; Rao and Rogers, 2006). Additionally, it has been suggested that environmental indicators can only address the concept of sustainability if they take into account the temporal scale and have a target in mind (Meadows, 1998).

While many sustainability indices rely heavily on economic indicators, recognition of the need for a stronger environmental component led to a new approach, the Pressure State Response model. This model was developed to highlight pressure on the environment, and it measures alterations to the environment and the resulting policies or programs (OECD, 1993). While the PSR model works well for environmental factors, it is less useful for describing the social and economic pillars of sustainability. In response, 
P. van Beynen, R. BRinkmann, AND K. van BEynen

Table 2. General sustainability measures.

\begin{tabular}{|c|c|}
\hline Sector & Sustainability Measure \\
\hline Government engaged in sustainability & $\begin{array}{l}\text { Several measures of government sustainability such as incentives for green } \\
\text { redevelopment }\end{array}$ \\
\hline Agriculture & $\begin{array}{l}\text { Green practices, availability of organic food, humane animal husbandry, access } \\
\text { to affordable food }\end{array}$ \\
\hline Building and development & $\begin{array}{l}\text { Presence of benchmarking, access to green building technology, sustainable } \\
\text { approaches to development and redevelopment, preserving historic buildings, } \\
\text { access to affordable housing }\end{array}$ \\
\hline Economic Development & $\begin{array}{l}\text { Green industry, green energy development, green job availability, green real } \\
\text { estate }\end{array}$ \\
\hline Tourism & Ecotourism, green hotels \\
\hline Energy & $\begin{array}{l}\text { Use of green energy, conservation availability, education on green energy and } \\
\text { conservation }\end{array}$ \\
\hline Natural Resource Management & $\begin{array}{l}\text { Preserve lands for future generations, provide access to out of doors, provide } \\
\text { outdoor exercise opportunities, protect habitat of endangered species }\end{array}$ \\
\hline Transportation & $\begin{array}{l}\text { Provide green public transportation, develop green fuels and vehicles, build for } \\
\text { walking and biking }\end{array}$ \\
\hline Waste & $\begin{array}{l}\text { Reduce waste generation, promote reuse and recycling, eliminate hazardous } \\
\text { wastes }\end{array}$ \\
\hline Education & $\begin{array}{l}\text { Teach about sustainability in public schools, higher education options, informal } \\
\text { education efforts }\end{array}$ \\
\hline Water & $\begin{array}{l}\text { Conserve water, fresh water access to public, storm water management, } \\
\text { appropriate sewage management }\end{array}$ \\
\hline Greenhouse Gas Management & Plan in place for greenhouse gas management, inventory complete \\
\hline
\end{tabular}

the DPSIR model was created, whereby the driving forces (D) arise through society's use of natural resources to stimulate the economy, thereby exerting pressure $(\mathrm{P})$ on these resources. The state (S) of the environment describes the results of this pressure, and impact (I) includes the health and biological effects due to the state of the environment. Both the state and the impact lead to a response (R) in society that can include environmental policies, taxes, and regulations (Lundin, 1999). This latter model provides a comprehensive treatment of sustainable development. Similar approaches to those described above have been taken by the US Environmental Protection Agency in their Report on the Environment (US EPA 2008), the Heinz State of the Ecosystem report (H. John Heinz III Center for Science, 2008), and the Millennium Ecosystem Assessment (Hassan et al., 2005).

While many of these sustainability indices strive to describe all facets of sustainability, an unintended outcome is unwieldy indices that hinder effective translation of the local state of the environment into concrete regional or national courses of action (Ronchi et al., 2002). One method of portraying the results of the application of a certain index is to use the dashboard approach, a simple visual display that clearly delineates to the public and policy makers the current state of sustainability for the location (Ronchi et al., 2002).

In this study, we take a modified approach in the creation of a sustainability index specifically created for karst environments by integrating relevant environmental, economic-resource use, and social indicators. The Karst Sustainability Index (KSI) attempts to address a specific landscape type, an approach that cannot be used in larger national indices. Our index incorporates both qualitative and quantitative variables, similar to that undertaken by the Karst Disturbance Index. The KSI uses a set of core indicators that capture the specificity of karst environments, and it sets targets that can be actionable goals for municipalities to measure their success at living with karst in a sustainable manner. We believe that the results of this effort make a strong case for the development of regional sustainability indicators that make sense within particular environments.

\section{Criteria for Assessing Sustainability}

The U.S. Environmental Protection Agency states that the criteria for selecting indicators for environmental indices are that they be measurable, sensitive, reproducible, representative, have reference values, cost effective, easily detected, widely accepted, and understandable (US EPA, 2008). The PICABUE method of Mitchell et al. (1995) as described by Sunkar (2008) includes seven criteria to be considered when developing sustainability indicators: 1) Indicators must specify the sustainability principles to the applied. 2) Indicators should identify issues that are both locally and globally important. 3) Indicators should 
be constructed according to stated program objectives. 4) Indicators should address principles of equity, futurity, and environment to communicate progress towards sustainability. 5) Indicators should include local attributes that relate to administrative boundaries. 6) Indicators must consider uncertainty that arises from limited knowledge, poor datasets, and unpredictable behavior of the system. 7) Indicators should be assessed whether they are relevant to issues of concern, sensitive to change across space and social groups, temporally sensitive, supported by data, understandable, measurable, expressed in way that makes sense, and able to identify targets and trends to show progress, or lack thereof, towards sustainability.

As stated above, sustainability indices attempt to include most measures of sustainable development while environmental indices take the approach of measuring individual components of the entire environment. Hence the Karst Sustainability Index is somewhat of a hybrid, dealing directly with sustainable practices that are undertaken in karst settings. Overall selection criteria for indicators were:

1) Incorporate environmental, economic, and social components of sustainability.

2) Within these components, characteristics of karst are recognized.

3) Comprehensive treatment of all human activities related to environmental management.

4) Variables are meaningful for any karst landscape.

5) Variables can be easily and inexpensively measured.

The KSI is divided into the three domains, social, environmental, and economic-resource use. The rationale for taking this approach is to fulfill the criteria identified by Mitchell et al. (1995) that are outlined above. Accordingly:

1) The KSI is similar to more traditionally accepted measures of sustainability indices, but still captures karst-specific indicators.

2) The indicators are quantifiable, with little subjectivity, although there may be some debate about the targets for certain indicators.

3) Users can easily determine how far they are from these targets.

4) It is possible to visually display the results of our index to non-specialists using the dashboard approach.

5) This approach can be applied equally to all karst environments, in both rural and urban areas.

6) The KSI can show temporal change in these indicators over a defined period, measuring progress towards the targets.

Table 3 lists some of the many different practices and measures that pertain to karst and sustainability. All the variables outlined in the KSI can be applied to any karst region in the world, whether it is within a developed or developing nation. Finally, all the variables are easily measured and do not require field measurements, making the KSI very cost-effective. All that is needed is expertise in karst environments and knowledge of the management practices utilized in that region. The latter may involve some research and interviewing of local officials, but such an endeavor is not prohibitive in time or cost.

\section{The Karst Sustainability Index}

The three principal domains, social, environmental, and economic, each possesses a subset of indicators and target levels that determine progress towards sustainability (Table 4). The time frame over which these targets are achieved depends on the ability of the entity with jurisdiction over the karst region. This ability may be affected by the current state of the environment under the controlling body's jurisdiction. If the environment is already well managed, then little time and effort would be required to move the KSI indicators below the targets outlined below. However, if the opposite situation applies, with a heavily disturbed environment or with little political or economic will, the time to achieve the KSI goals may be greater. In light of this issue, it is up to the managing entity to determine what time frame is reasonable. Each domain contains several indicators. Their inclusion is justified below.

Social Domain. The social domain is complex and includes a variety of indicators, including issues of equity and environmental justice, indigenous peoples' rights, and the ability of local residents to obtain work and take part in governance. These are covered in the first five indicators. As this index is applied to karst environments, these indicators have karst-related themes, with local ownership of caves, local employment in karst jobs, and equitable access to karst resources for native people.

Education is an essential component of any sustainability index, regardless of scale or environment, and our index is no exception. However, once again, the education indicators concentrate on karst and how schools, tourist facilities, and local governments take advantage of their local karst setting to inform the public about the issues and fragility of their environment.

Environmental Domain. The environmental-domain indicators are concerned with the sustainable environmental management of karst landscapes. A variety of indicators, from surface practices to water quality to environmental monitoring, are included. Caves and surface karst have extremely fragile and rare biota and flora that can be easily disturbed. Consequently, their preservation is imperative to the biodiversity of the planet. If these species are to be protected, areas around the caves should be forested or protected from development. The prevention of widespread deforestation, especially in native forests, can prevent accelerated soil erosion, thereby reducing cave sedimentation and negative impacts on cave biota. In addition, 
P. van Beynen, R. BRinkmann, AND K. van BEynen

Table 3. Sustainable practices to reduce human impact on karst environments.

\begin{tabular}{|c|c|}
\hline Uses/Components & Sustainable Practices \\
\hline \multicolumn{2}{|l|}{ Quarries } \\
\hline Opencast & $\begin{array}{l}\text { Reclamation after use/avoid caves/placement to reduce alteration of hydrology/containment of } \\
\text { waste }\end{array}$ \\
\hline \multicolumn{2}{|l|}{ Mining } \\
\hline Underground & $\begin{array}{l}\text { Minimize hydrology alteration/protection of groundwater from contamination/reduction of } \\
\text { possible subsidence/ fewest mines possible }\end{array}$ \\
\hline \multicolumn{2}{|l|}{ Agriculture } \\
\hline Extensive & $\begin{array}{l}\text { Prevention of overgrazing/minimal fertilizer and pesticide use/erosion reduction measures/setbacks } \\
\text { around sinkholes, springs and caves }\end{array}$ \\
\hline Intensive & $\begin{array}{l}\text { Contain effluent runoff/reduced chemical use/prevent alteration of hydrology/monitor water } \\
\text { quality }\end{array}$ \\
\hline \multicolumn{2}{|l|}{ Forestry } \\
\hline Logging & $\begin{array}{l}\text { No clearcutting/minimize hydrological alteration/erosion control measures/ creation of setback } \\
\text { zones around caves and springs/ no use of chemicals/active management and monitoring of caves/ } \\
\text { monitor water quality }\end{array}$ \\
\hline \multicolumn{2}{|l|}{ Tourism } \\
\hline Springs & $\begin{array}{l}\text { Pollution reduction measures within spring catchments/control of water extractions/control of } \\
\text { development in spring catchment/erosion control in catchment to prevent clogging/public } \\
\text { education }\end{array}$ \\
\hline Caves & $\begin{array}{l}\text { Effective management plan and installation of plan/monitoring of cave and surface connections/ } \\
\text { protection of cave surface catchment/public education }\end{array}$ \\
\hline Surface features & $\begin{array}{l}\text { Prevention of removal of features/management and monitoring plan/effective enforcement/public } \\
\text { education }\end{array}$ \\
\hline \multicolumn{2}{|l|}{ Urban Landuse } \\
\hline All categories & $\begin{array}{l}\text { Effective laws and regulations to prevent pollution of aquifers (long list of possibilities here)/ } \\
\text { reduction in impervious surfaces/increase urban forests }\end{array}$ \\
\hline \multicolumn{2}{|l|}{ Water Use } \\
\hline Withdrawals & $\begin{array}{l}\text { Effective management and monitoring of aquifer/regulations, laws and enforcement of these are } \\
\text { fundamental }\end{array}$ \\
\hline Dumping/disposal & $\begin{array}{l}\text { Effective laws and enforcement to make sure contaminant levels at safe levels regardless of seasonal } \\
\text { changes in hydrology/public education/monitoring }\end{array}$ \\
\hline
\end{tabular}

riparian zones around hydrologic inputs to the karst can reduce sedimentation and also remove some contaminants harmful to the karst groundwater.

Measures of the quality of the water, common in all environments, can be biological in origin, such as biological oxygen demand or chlorophyll B. Elevated nitrate levels are also seen as problematic and are commonly measured. To maintain water quality at acceptable levels, monitoring is necessary, though it is unrealistic to expect every small stream to be monitored. Another consideration in assuring the sustainability of karst-water resources is reducing the likelihood of their contamination from landfills and waste water-disposal. Industrial and residential wastes can easily contaminate groundwater, and their collection and treatment are vital to prevent pollution. Karst aquifers and their associated outflows (springs) are especially vulnerable to groundwater contamination due to rapid infiltration through the epikarst and quick flow-through times of groundwater via natural conduits. In non-karst lands, bacterial degradation and filtering is common, but in karstified bedrock, it is uncommon. Indicators En7-9 provide viable targets for municipalities to achieve sustainable use of this resource. Modern design of landfills is a safeguard for groundwater, and residential wastewater must be collected and treated properly.

As part of management plans, the condition of caves, especially those that have regular visitation or are commercial, should also be monitored to ensure this karst resource is not being degraded. Regulations can help with these measures, and their enforcement is imperative.

Economic Resource Use Domain. Finally, the economic domain focuses on economic activities and local resource

Journal of Cave and Karst Studies, August 2012•225 
Table 4. The three principal domains, social, environmental, and economic of The Karst Sustainability Index.

Indicator

Target, $\%$

\section{Social Domain}

S1. Local ownership, private or public, of caves and springs

S2. Locals employed in karst-related jobs

$>80$

$>80$

100

S3. Equitable access for population to karst water resources

$<5$

100

100

S6. Percentage of schools offering karst education in curriculum

100

S7. Percentage of karst-related tourist facilities offering informal education

100

S8. Local governments offering karst-related information on websites or through publications

Environmental Domain

En1. Increase in amount of karst area forested or in native vegetation

En2. Increase in amount of karst area designated protected

En3. Biodiversity of species in karst environment

En4. Riparian zones around sinking-streams and sinkhole sources

En5. Decrease in number of impaired springs as measured by biological or water quality indicators

$\downarrow 20$

En6. Percentage of water-supply springs and wells that are monitored

100

100

En7. Current landfills preventing groundwater contamination

100

100

En9. Tertiary treatment of urban wastewater

100

100

En11. Enforcement of local regulations

100

Stable

$\uparrow 20$

Stable

100

$\uparrow 20$ use. The indicators measure whether particular practices within the karst landscape can be considered sustainable.

Quarrying and mining are destructive activities, but can also be important sources of income. The sustainable practice of quarrying and mining should focus on ensuring long-term plans for reclamation. The sustainable use of karst water resources such as aquifers and springs is essential, and consumption from these per capita should decrease with time. Greater efficiency and conservation practices that make such a goal attainable are currently available. The agricultural sector is an important source of income for most karst regions, but in some locations it extracts more water from aquifers than any other user. To determine the water sustainability of this sector, one approach would be to divide the value of agricultural output by its water use; for an improvement in sustainability, this ratio should increase over time.

The development of urban areas is often seen as economic progress. However, such development also requires more resources and adds stress to the karst landscape via deforestation and increased stormwater runoff. The karst hydrology of an area is often altered during this process through soil compaction, grouting of subterranean voids, and the interception of precipitation before it enters the epikarst. Restricting the growth of urban areas maintains agricultural areas and forests. Their preservation allows for natural infiltration rates into the epikarst, resulting in less groundwater pollution. Higher population density of urban areas is a likely consequence, but indirectly achieves one of the aims of sustainability, the reduction of our carbon footprint. Commercial forestry needs to be sustainable if it is to survive. Widespread removal of native forests simply depletes this finite resource. Selective logging of the larger native trees allows the smaller ones to replace them for future harvesting. However, if native forests have already been felled, replanting is essential.

Ecotourism is a growing trend in many countries where the natural environment is impressive enough to draw visitors from around the world. Many karst areas have the necessary physical features such as caves, tower karst, or large springs to draw the tourists. Best practices of ecotourism attempt to reduce the human impact on these features by limiting numbers and reducing the building of infrastructure at these sites. 


\section{RATIONALE OF TARGETS FOR INDICATORS OF KSI}

\section{Social Domain}

The World Commission on Environment and Development (1987) argues that greater equity will lead to more sustainable development. "Poverty itself pollutes the environment... Those who are poor and hungry will often destroy their own immediate environment in order to survive." Local ownership and local employment levels are set at greater than $80 \%$ to ensure that the local community has significant control and involvement in the local economy. External entities often take control of local resources with little concern for improving the quality of life and incomes of people in the surrounding area. Where this is true, sustainable practices should include local stakeholders into the decision-making process rather than relying on external paternalistic control of the economic resources. Urich et al. (2001) provide an excellent example of including local vested interest groups in this process. Local participation and oversight of resource extraction focused on the long term needs of the people and the karst environment is crucial for sustainable practices. Related to these indicators are those pertaining to equity and social justice. All of the population should have access to the water supplies of the area, in accordance with the $2010 \mathrm{UN}$ declaration that water and sanitation are basic human rights (Banerjee, 2010). Additionally, displacement of local populations can result from the development of important economic resources. Two examples of this displacement of local population due to the exploitation of natural resources in karst environments are the development of the Three Gorges Dam in China, which required the relocation of more than a million people (Heming et al., 2001) and the expansion of mining operations in Jharkhand, India, which led to subsequent environmental degradation that caused the displacement of the local indigenous peoples (Areeparampil, 1996). This is unfortunate, and it should be kept to a minimum; hence we set the target for the displacement of the local population at $5 \%$. Where population densities are high, even a small percentage can be a large number of people, and the target can be set lower in such cases (Ronchi et al., 2002).

Indigenous peoples should have access to their karst resources, especially if they used these for many years. Indigenous needs may seem unusual to our Western culture, but this should not affect access. Two examples are access to caves that are traditional burial sites and preservation of sites of religious or cultural significance.

Ideally, the most effective approach to promote sustainable use of karst landscapes is education. Schools in a karst region should offer some type of karst-related education. Tourist caves offer a rare opportunity to educate the general public. During most cave tours, a small amount of scientific information is given to tourists, so there could be subtle inclusion of how we can improve our interactions with the surface and subterranean karst environment. There is no reason why $100 \%$ of tourist caves cannot achieve this target. Finally, to encourage public interest in their effects on their karst environment, $100 \%$ of local governmental agencies should have information on their websites or written information available to the public at their offices.

\section{ENVIRONMENTAL DOMAIN}

Sedimentation of streams and rivers is a real threat to vulnerable karst ecosystems. The area of forest and protected karst should be increased by a target of $20 \%$ over a designated period of time. Karst is known to have species that are endemic to small areas such as caves. In fact, certain species have been identified that can only be found in one cave. These can include certain types of isopods, aquatic species, and plants (Christman et al., 2005). It is essential that all species are kept stable and that no species go extinct. One approach to protecting species is to remove eroded sediment or contaminants before they reach streams by replanting and preserving riparian zones along waterways. Most waterways should possess riparian barriers, and $75 \%$ is a realistic target for a significant difference in water quality to be achieved.

It is also important to reduce the number of impaired water bodies if a sustainable water resource is to be maintained for future generations. Reducing the number of water bodies that are impaired by $20 \%$ is not an excessive or unattainable goal given certain best management practices and small changes in consumer behavior. Agricultural practices are a significant cause of water degradation, and best management should be adopted in this sector. These practices include sustainable logging instead of clear-cutting, keeping pesticide use to below $7.5 \mathrm{~kg} / \mathrm{ha}$ (Ronchi et al., 2002), and ensuring there is a reduction of soil erosion and overgrazing of $50 \%$ over the target period. Monitoring the water quality of all municipal springs and wells is essential for not only safeguarding drinking water supplies but also allowing the rapid identification of sources of pollution that may negatively impact this vital resource for some time. In addition to these measures, leachates from landfills and untreated sewage must not be allowed to become pollutants. To attain such a target, all landfills must have liners to prevent leachates escaping. All sewage must be directed to treatment plants in urban areas, and rural areas can have large receptacles that can be emptied when necessary. Such companies already exist to remove human effluent from point sources such as homes.

Monitoring the condition of caves will determine if any surface activities are having a detrimental effect. Heavily used caves, especially those that are commercial entities, should undertake monitoring that includes counting cave species, measuring $\mathrm{CO}_{2}$ concentrations, watching for lampenflora, and observing the condition of speleothems. Finally, enforcement of environmental regulations related to the above indicators would help government agencies 
meet their targets and reduce environmental degradation. While the target of $100 \%$ enforcement of environmental regulations is ambitious, it is an important goal for municipalities, due to the particular fragility of their karst environment.

\section{ECONOMIC Domain}

Due to the extreme destructiveness of quarries, it is important to reduce the impact of this sector of the economy. Best management practices for this sector include the rehabilitation and reclamation of those sites where commercial operations have ceased. One way to quantify this approach is to simply require a decrease in the amount of bedrock or minerals extracted from area. A realistic target that would not destroy a local economy reliant on this sector would be a reduction of $20 \%$ of extracted material.

In most developed nations water consumption far exceeds what could be needed given more conservative practices. Excess consumption leads to falling water tables and decreases in water quality. Reduced water levels impact karst by affecting percolation rates to caves and by allowing rapid saltwater intrusion in coastal areas. A $20 \%$ reduction in water consumption over the designated time period is possible, as evidenced by experiences during droughts that required conservation measures. A reduction in water use by the agricultural sector is an important goal for the sustainable use of the karst aquifer. Here the KSI requires an increase of $20 \%$. Roadways and development of urban areas are essential components of economic development. However, such development can be contained within existing areas or brownfields through the intensification of land use, so as not require additional roadways and to make mass-transit systems more viable.

The forestry sector, especially one that destroys native forests, is not usually sustainable, and even exotic forests can struggle in karst areas where thin soils predominate. A target that calls for $100 \%$ of the forestry sector to practice sustainable harvesting techniques is reasonable, and it would allow for long-term employment in this industry. Finally, ecotourism is seen as the future of the sustainable exploitation of the natural beauty of an area. By increasing these types of ventures by $20 \%$, the end product would be less impact on the karst landscape and a better-educated tourist.

\section{Application to the Tampa Bay Metropolitan Area}

West-central Florida's Tampa Bay Metropolitan Area consists of four counties, Hernando, Hillsborough, Pasco, and Pinellas (Fig.1). While they may differ somewhat in their land use, they all fall within the same karst area characterized by flat terrain, a high density of sinkholes, a highly utilized aquifer, and important springs. The population of 2.5 million has led to karst degradation and karst-related environmental problems (Tihansky and
Knochenmus, 2001). The Ocala and Suwannee Limestones constitute the bedrock that lies below meters of poorly drained clay to sandy-clay sediments interspersed with calcareous rock (the Hawthorn Group) (Stankey, 1982). The TBMA covers $6,637 \mathrm{~km}^{2}$, with Pinellas and Hillsborough Counties holding most of the population in the region and Pasco County in transition from being predominantly rural to hosting low-density residential communities. Hernando County is rural, with only 106 people per $\mathrm{km}^{2}$, and it also contains all the vadose caves in the TBMA. Conduits in the rest of the region are all phreatic in nature.

\section{Data Sources}

Data for equity and environmental justice measures in the social domain such as ownership, employment, access, displacement, and indigenous rights for the areas of interest can only be gathered by local data collection, policy assessment, and interviews. Information on karst education in school curricula, education centers, and tourist locations can be gathered from school officials, education centers, and cave managers. For the Tampa Bay Metropolitan Area study, all of the necessary information we already knew from our work in the area or was found on county, state, and federal government websites. Consequently, data collection was fairly straightforward.

The environmental domain has a number of data sources. Local or regional councils or governmental agencies can be a wealth of information on forests, protected areas, riparian zones, and the monitoring of various water-quality indicators. They may also be responsible for enforcing local and national environmental regulations. Departments of environmental protection or conservation, if they exist, often measure the state of the environment for areas under their control. In addition, all these agencies may have GIS map files and spatial data that can be invaluable in illustrating changes that have occurred in their regions. Cavers and cave organizations possess a wealth of information that should not be ignored, particularly regarding cave management plans and eco-tourist activities. The TBMA study confirmed these sources of data were essential and often readily available from individuals and organizations like the South West Florida Water Management District. Relevant regulations were found in county management plans. Florida state agencies, such as the Department of Environmental Protection, also collected useful data. In addition, research by universities is another important source of environmental data for assessing the state of certain aspects of the karst environment.

Finally, information for economic or resource use indicators generally comes from local, regional, or national governmental entities. Data about water consumption and waste collection and treatment are typically collected by local municipalities or waste and water management organizations. Regulations that influence landuse and urbanization can be assessed at the local, regional, and national levels. For the TBMA, these data had been 
created by the SWFWMD and groups at local universities such as the Institute of Food and Agricultural Sciences.

\section{SCALE}

There are various scales at which a Karst Sustainability Index can be applied. These include large areas such as states or counties that encompass an entire area of karst, as well as small karst watersheds. Applications at both scales have their advantages and disadvantages. In large areas, all of the karst can be included, and any small local differences between areas can be smoothed. Data collection at this scale is facilitated by national and regional data networks. The obvious disadvantage to this approach is that major problems can occur when individual watersheds are ignored. In addition, while this approach may be more efficient, interagency cooperation is not always guaranteed. In the same vein, larger organizations often have different groups working on the same area without any communication, collaboration, or coordination.

The major advantage of working at the watershed level is being able to collect very detailed local data and information; this produces more accuracy in the assessment of sustainability. Another advantage is that it is possible to keep building the study area outwards from a single watershed to allow for comparative analysis.

During our application of the KSI, the issue of scale did not appear to be a problem. Although the study area contains several large watersheds, they are fairly homogeneous in their geology, and, given that the area is entirely karst, this greatly simplified the process. If the KSI had been applied to the entire state of Florida, then issues associated with scale would have been more apparent. Much of our data came from the SWFWMD, but Florida is divided into five water management districts, and there would be no guarantee that all the required data would be available or directly comparable.

The results of the Karst Sustainability Index can be seen in Table 5. Progress towards the KSI targets for the TBMA was measured between the years 1997 to 2010 or less, depending on the period for which data were available. While a ten-year period was the most common time over which progress was measured, only a shorter span of data could be collected for certain indicators; our shortest period of data was five years. The social domain (Table 5) was the component that demonstrated the region's most effective efforts towards sustainability. All major springs are under the authority of the South West Florida Water Management District. Of the caves in the TBMA, they are, with the exception of one, all within Florida State Forest holdings or are privately owned by local residents. Karst-related employment, whether at the water management authorities or spring attractions, is locally derived. With the TBMA being in a developed country, everyone has access to the water pumped from the karst aquifer. However, permits are required from the SWFWMD if significant amount of water is extracted by commercial entities.
While displacement of a segment of a population may be common in developing countries and indigenous peoples access to the karst resources may be restricted, these two indicators are not applicable for the TBMA. Although the entire school population of the region resides on karst, most schools in the area do not receive any education on the karst landscape, but several schools with an environmental focus in the Tampa area have been visited by graduates of the University of South Florida for talks on karst-related matters. Among the state environmental teacher-training programs uncovered, only one fieldtrip to a sinkhole has been incorporated into the science section, and no specific teaching module on karst exists. While formal education is somewhat lacking in teaching the children of TBMA about their environment, the springs that are tourist attractions, such as Homosassa and Weeki Wachee Springs, provide karst-specific information via display boards describing the formation of springs and the importance of the karst aquifer to the populace. Local government and water-authority agencies produce brochures and have information on their websites pertaining to the sustainable utilization of the local karst resources.

For many karst regions, the environmental domain poses the greatest challenge to achieving sustainability. Table 5 shows that the TBMA has a somewhat mixed record when it comes to sustainability. Over a ten-year period from 1996 to 2006, there has been a decrease in the region's forests by $10 \%$ (Hernandez et al., 2010). However, the need to protect the aquifer that is the main source of the region's drinking water has resulted in land acquisition by local government agencies. For example, in 1997 SWFWMD was authorized to acquire 600,000 acres, and by 2001360,000 acres had been bought. By 2010 that total had risen to 444,000 acres. The target of 600,000 acres was not achieved due to the severe economic downturn in Florida (SWFWMD 2001, 2011b), but the area of karst that is protected has increased as a result of this process. The indicator pertaining to riparian zones is directly related to this increase in the lands that have been acquired. In addition, regulations and management plans (e.g., the 2011 plan in Hernando County) for all the counties call for either setbacks around sinkholes or the exclusion of these features for stormwater drainage (Florida Administrative Code Rule 62-28.700).

The decline in the TBMA forests but an increase in protected land creates a difficulty in determining how biodiversity has been affected. The clearing of forests occurred decades prior to SWFWMD's land acquisition (Janicki et al., 2001). In addition, many wetlands were drained, and deforestation continues. The overall reduction of the TBMA forests and wetlands implies a decline in biodiversity. Countless studies from around the world that have measured the effects on biodiversity of such environmental changes would confirm this assumption (Lawton et al., 1998; Brook et al., 2003). However, local 
Table 5. Scores for the three principal domains, social, environmental, and economic of The Karst Sustainability Index.

Indicator

Social Domain

S1. Private or public local ownership of caves and springs

S2. Locals employed in karst-related jobs

S3. Equitable access for population to karst water resources

S4. Percentage of population displaced by urbanization of karst landscape

S5. Indigenous peoples access to karst resources

S6. Percentage of schools offering karst education in curriculum

S7. Percentage of karst related tourist facilities offering informal education

S8. Local governments offering karst related information on websites or through publications

Environmental Domain

En1. Amount of karst area forested or in native vegetation

En2. Amount of karst area designated protected

En3. Biodiversity of species in karst environment

En4. Riparian zones around hydrological input sources to karst groundwater

En5. Number of impaired springs as measured by biological or water quality indicators

En6. Number of monitored municipal springs and wells that are used for water supply

En7. Current landfills preventing groundwater contamination

En8. Collection of sewage from all homes in urban areas

En9. Tertiary treatment of urban waste water

En10. Monitoring of the condition of heavily used caves

En11. Enforcement of local regulations

Economic Domain (Resource Use)

Ec1. Non-operational commercial quarries or mines that have been reclaimed

Ec2. Water extraction from aquifer and springs

Ec3. Agricultural sales (\$ per year)/water use (mgd)

Ec4. Area of urbanization and roads

Ec5. Sustainable forestry on the karst landscape

Ec6. Number of eco-tourism ventures related to karst landscape
Progress Towards Target

Achieved

Achieved

Achieved

N/A

N/A

$<10 \%$

Achieved

Achieved

Declining

Increasing

Declining

Increasing

Declining

Achieved

Achieved

Achieved

Achieved

Increasing

Increasing

Increasing

Increasing

Achieved

Decreasing

Increasing

Stable caves are relatively undisturbed due to lack of public access or knowledge, and those that do receive frequent visitors have cave management plans either by karst conservation associations or the Withlacoochee State Park.

Unfortunately, water quality in the TBMA has declined as measured by nitrate levels in streams that emerge from springs or drain into the aquifer. Elevated nitrate levels increase algae in the water, reducing dissolved oxygen, which negatively impacts aquatic biota. Of the 191 water bodies measured, 116 of these have been classified as impaired based not only on nitrate levels but also on other biological assessments. Additionally, there has been a 31\% increase in the region's springs that are deemed degraded by the water-management district (SWFWMD, 2011b).

Monitoring allows the region's resource managers to identify areas of special concern that require mitigation efforts. All the major first and second order springs that are used for municipal drinking-water supplies are monitored, as are the wells that extract water from the aquifer for the same purpose. No cave monitoring in the TMBA exists.
Finally, the enforcement of the regulations that protect the karst landscape and its waters from negative human impact are measured by fines and consent orders, which are agreements between the Florida Department of Environmental Protection and the offending party. Fines that have been levied have increased by $35 \%$, and the average number of consent orders for the four counties from 1995 to 2005 has increased by $55 \%$. It should be noted that this figure is elevated by Hernando County, which had an increase over this period of $91 \%$ (North et al., 2009).

Limestone and phosphate quarries are the two main factors in the economic domain for the TBMA. Phosphate mining is concentrated in eastern Hillsborough County, while limestone quarrying only occurs in Hernando County. The Florida phosphate industry has been required to reclaim their open-cast mines under the Mandatory Phosphate Program (MANPHO) since 1975. The program administers the rules of the legislation on Environmental and Wetland Resource Permits for phosphate-mined lands. (Chapters 378, Part II, and 373, Part IV, Florida Statutes; Chapters 62C-16, 62-312, 62-4, 62-343, 62-341, and 40X-4, 
Florida Administrative Code). The law created a voluntary trust fund that helps fund the reclamation of lands disturbed prior to this legislation (http://www.dep.state.fl.us/ water/mines/manpho.htm). Although the reclaimed land does not possess all the biodiversity and character of the natural landscape, this approach is better than the alternative of no reclamation at all, as was the case prior to 1975 . Hernando County has a history of reclamation of limestone quarries. In 1992 and 2002 two quarries were transformed into golf courses and residential developments after gaining approval from the Hernando County Commission (http:// quarrypreserve.info/pdf/qp_quality_development.pdf). A preferable alternative would have been to return these sites to their original natural state instead of approving two land uses that do not fit the ideal of sustainable development. Consequently, while TMBA has seen some progress towards reclamation, some reclamation efforts are questionable. There are many non-operational phosphate mines and limestone quarries that still require rehabilitation.

Water extracted from the aquifer and springs decreased in TBMA from 123 to 101 gallons/day/capita on average for the period 2001 to 2009 (SWFWMD, 2004a, 2011b). This decrease has been achieved through incentives such as community education and rebates for more efficient irrigation systems and other water-saving technology. For improved agricultural usage of groundwater, west-central Florida improved its efficiency by 21\% from 1997 to 2007 (US Department of Agriculture, 1999, 2009; SWFWMD 2003, 2004a, 2004b, 2009, 2011a). Pinellas County is not included in the calculation as it contributes very little to the agricultural production of the area.

The changing area of urbanization is often an indicator of economic growth, and the TBMA is an excellent example of this. For sustainable use of the karst landscape, this area should not increase, but the TBMA has seen a 21\% increase from 1996 to 2006 (Hernandez et al., 2010). However, this rate of growth has slowed dramatically with the economic downturn in the state. Logging is another economic activity that can be important to a local economy. While this sector is not a significant component of employment in the TBMA, there has been a shift towards a more sustainable use of this resource through the replanting of cleared forests with native species, particularly slash pine. However, a failure in this measure is that the area of forest in the region has declined over this period due to the increase in the urban footprint. Finally, tourism is an important source of income to the TBMA, but the karst landscape contributes little to this sector. The karstrelated tourist attractions are the springs of the area, particularly Homassassa and Weeki Wachee. These constitute sustainable eco-tourist entities, but the number of such ventures has not increased in recent years.

Every indicator for each domain is displayed (Fig. 2) using the dashboard approach similar to that used by Ronchi et al. (2002). It is readily apparent that the TBMA has achieved nearly all of its sustainability targets set by the KSI for the social domain. The region is also making progress in the environmental domain, with only three indicators showing no improvement or worsening conditions over the measured timeframe. In the economic domain much progress is still required, as none of the KSI targets have been achieved. Consequently, the overall rating of the KSI for the TBMA is that the region is progressing toward the target of sustainable development.

\section{Discussion}

We have provided a framework for measuring the sustainability of karst landscapes using an index that sets targets for government entities, taking into consideration issues of equity, environment, and economic development. As with any index, it is not possible to incorporate every aspect of sustainability. One measure we have struggled with is enforcement. It is recognized that while the simple creation of regulations protecting karst is laudable, their enforcement is just as important. However, there is no single method of enforcement to measure. Fines, imprisonment, loss of access, and requirement of restoration are all possible techniques. In addition, assessing enforcement within a sustainability index is difficult. In an attempt to measure this Karst Sustainability Index indicator in the Tampa Bay Metropolitan Area, we used consent orders, which are agreements between the regulators and offenders that the guilty party pays fines or the violations are to be rectified. As these consent orders increased over time, it was deemed that enforcement was improving. No region will be able to enforce regulations on every violator, but if these efforts are increasing, then this indicator can be included in the KSI.

Many sustainability indices applied at a national scale have economic indicators such as gross national project, per capita income, and employment rates. These types of measure do not have much bearing on a sustainability index developed for a specific environment at a local level. We initially considered as indicators the contributions of various karst-related industries to the local economy. However, collecting this data at municipal and county levels proved problematic. For example, when attempting to collect information on the quarrying and mining sector, we could only find data at the state level or for the entire company's operations that extended beyond the Tampa Bay area. It was impossible to find what we needed for the specific karst region we were investigating. The same issue arose with the commercial water-bottling industry.

Another approach to try to quantify certain industries was to collect employment data. For industries that are particularly unsustainable, such as mining, the desire is to see it decrease in significance in the region. However, an indicator that calls for a decline in employment seems inappropriate in a sustainability index that aims to balance the needs for human and economic development with 


\section{Tampa Bay Metropolitan Area}

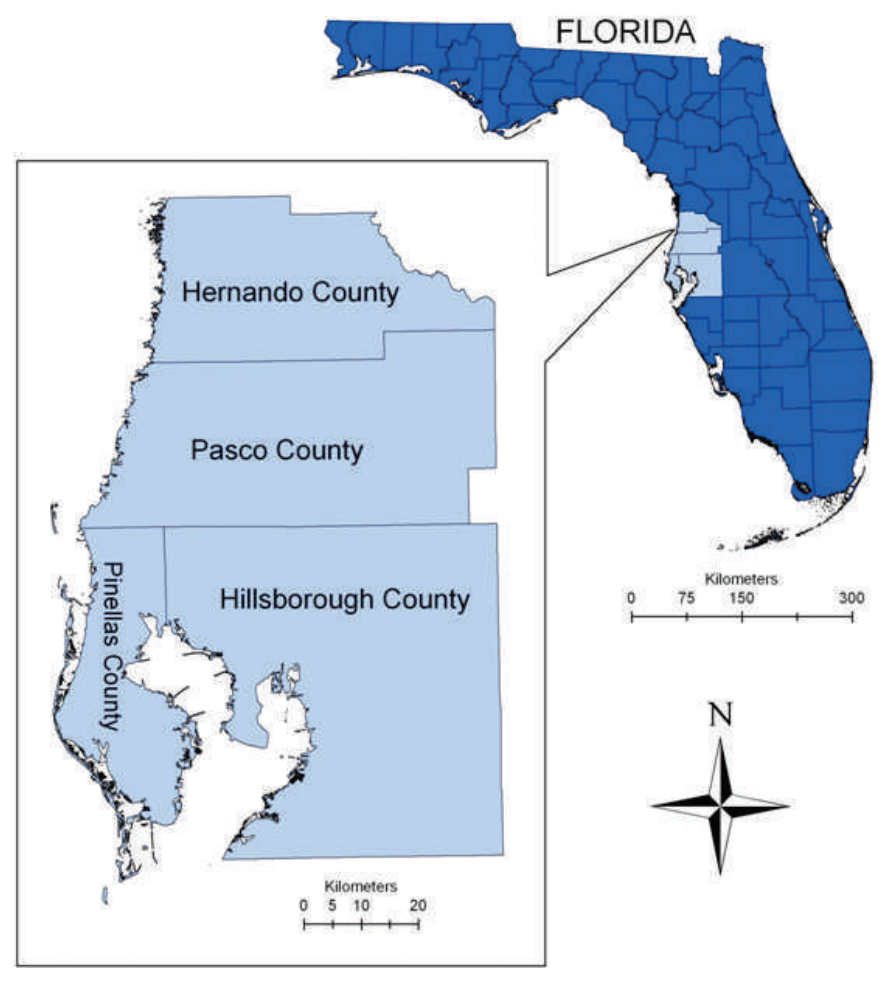

Figure 1. The Tampa Bay Metropolitan Area, Florida, USA.

preserving the quality of the environment. Finally, sales or financial data for major companies operating in the region were extremely difficult to come by or too general to be of any use. These issues lead us to concentrate on some very simple indicators where the data would be readily available.

Truth in reporting and uniform application is another possible limitation of any index. Company and government officials may feel it is more important to give the impression of sustainable operations and environmental stewardship. As such, third party evaluation and verification may be appropriate.

In developing countries where there are globally significant areas of karst (for example South East Asia or the Caribbean), shortages of both data and experts may be an obstacle to the implementation of the KSI. In some areas of the developed world, access to and use of natural resources are tightly controlled, but in many developing countries illegal logging, unsanctioned quarries, and unregulated water use are common, and in some cases government officials are unaware of or unwilling to address these problems. In addition, few individuals with specialized knowledge on the karst environments may be available. Consequently, the application of the KSI may be limited until the necessary data and experts are created. During information gathering in the TBMA to apply the

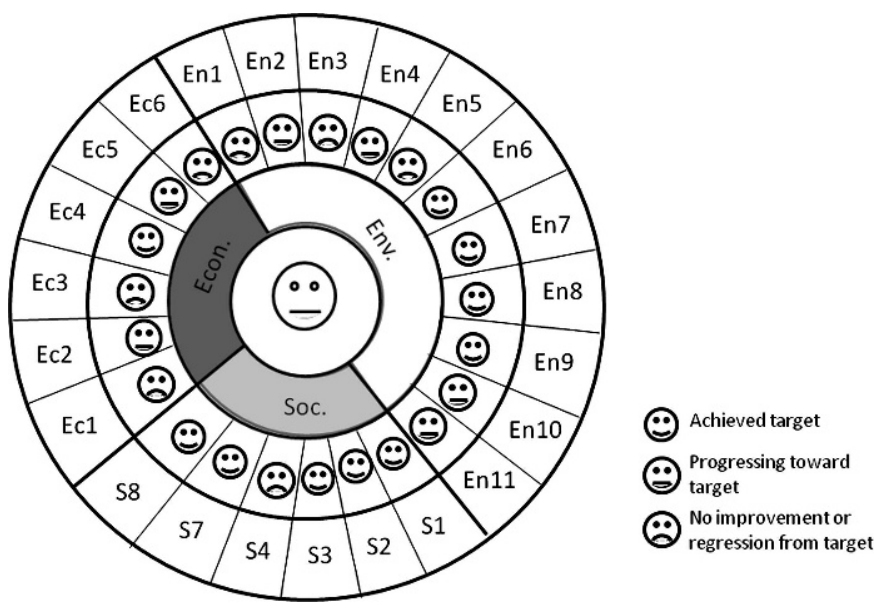

Figure 2. Dashboard display of progress toward sustainability in the Tampa Bay Metropolitan Area.

index, none of these issues arose. The data needed to score the indicators were available, with the exception of changes in biodiversity for the region. Even so, the values of related environmental indicators allowed a justifiable assumption to be reached of the state of biodiversity in the study area. Well-funded government agencies and a number of local university studies produced all of the data in reports that are readily available to the public. All that was needed was finding these reports and the collation of the data. We recognize that the aforementioned issues are still valid for many karst areas in developing countries.

\section{Conclusions}

In summary, a Karst Sustainability Index was developed that takes into consideration the three pillars of environmental sustainability to evaluate karst landscapes: social equity, environmental values, and economic development. The index differs from other karst management approaches in that it seeks to address issues of environmental sustainability, as defined by the Brundtland Report and the UN Millennium Goals (Dalby et al., 2009; United National Development Program, 2003). Several specific variables are measured within each of the three domains that can be mapped and assessed with a GIS. The KSI is a useful tool for assessing overall environmental sustainability to manage karst landscapes, as demonstrated by the application to the Tampa Bay Metropolitan Area. Our society, local governments, businesses, and other organizations are seeking ways to measure and benchmark sustainability within their communities, and the KSI provides a framework for assessment within karst lands. While the index has limitations, the KSI is the first to attempt to address broad sustainability issues within this unique landscape. However, in TBMA study these limitations were found to be minimal. 


\section{REFERENCES}

Areeparampil, M., 1996, Displacement due to mining in Jharkhand: Economic and Political Weekly, v. 31, no. 24, p. 1524-1528.

Banerjee, T., 2010, Right to water: some theoretical issues: Contemporary Issues and Ideas in Social Sciences, v. 6, no. 1, Available at: http:// journal.ciiss.net/index.php/ciiss/article/view/79/76. [Date accessed March 8, 2011]

Briggs, D.J., 1998, State of Environment Reporting, in Nath, B., Hens, L., Compton, P., and Devuyst, D., 1998, Environmental Management in Practice, Volume 1: Instruments for Environmental Management. London, Routledge, p. 90-106.

Brinkmann, R., and Garren, J., 2011, Karst and Sustainability, in van Beynen, P.E., ed., Karst Management: Dortrecht, Springer, p. 361-378.

Brook, B.W., Sodhi, N.S., and Ng, P.K.L., 2003, Catastrophic extinctions follow deforestation in Singapore: Nature, v. 424, p. 420-423, doi:10.1038/nature01795.

Calò, F., and Parise, M., 2006, Evaluating the human disturbance to karst environments is southern Italy: Acta Carsologica, v. 35 , no. 2 , p. $47-56$.

Chapagain, A.K., and Hoekstra, A.Y., 2004, Water Footprints of Nations, Volume 1: Main Report: Delft, Netherlands, UNESCO Institute for Water Education, Value of Water Research Series 16, 76 p.

Christman, M.C., Culver, D.C., Madden, M.K., and White, D., 2005, Patterns of endemism of the eastern North American cave fauna: Journal of Biogeography, v. 32, no. 8, p. 1441-1452, doi:10.1111/ j.1365-2699.2005.01263.x.

Culver, D.C., and Pipan, T., 2009, The Biology of Caves and Other Subterranean Habitats: Oxford, Oxford University Press, 254 p.

Dalby, S., Brauch, H.G., and Spring, Ú.S., 2009, Environmental security concepts revisited during the first three phases (1983-2006), in Brauch, H.G., Spring, Ú.O., Grin, J., Mesjasz, C., Kameri-Mbote, P., Behera, N.C., Chourou, B., and Krummenacher, H., eds., Facing Global Environmental Change: Environmental, Human, Energy, Food, Health and Water Security Concepts: Berlin, Springer-Verlag, Hexagon Series on Human and Environmental Security and Peace, v. 4 , p. $781-790$.

Day, M., Halfen, A., and Chenoweth, S., 2011, The cockpit country, Jamaica: boundary issues in assessing disturbance and using a karst disturbance index in protected areas planning, in van Beynen, P.E., ed., Karst Management: Dortrecht, Springer, p. 399-414.

De Waele, J., 2009, Evaluating disturbance on Mediterranean karst areas: the example of Sardinia (Italy): Environmental Geology, v. 58, no. 2, p. 239-255, doi:10.1007/s00254-008-1600-x.

Fleury, S., 2009, Land Use Policy and Practice on Karst Terrains: Living on Limestone: Springer, $187 \mathrm{p}$.

Ford, D.C., and Williams, P.C., 2007, Karst Hydrogeology and Geomorphology: Chichester, England, John Wiley and Sons, 562 p.

H. John Heinz III Center for Science, Economics and the Environment, 2008, State of the Nation's Ecosystems 2008: Measuring the Land, Waters, and Living Resources of the United States: Washington, D.C., Island Press, $352 \mathrm{p}$.

Hassan, R.M., Scholes, R., and Ash, N., eds., 2005, Ecosystems and Human Well-Being: Current State and Trends Assessment: Findings of the Condition and Trends Working Group of the Millennium Ecosystem Assessment: Washington, D.C., Island Press, The Millennium Ecosystem Assessment Series 1, 948 p.

Heming, L., Waley, P., and Rees, P., 2001, Reservoir resettlement in China: past experience and the Three Gorges Dam: The Geographical Journal, v. 167, p. 195-212.

Hernández, J., Davis, A., Huang, S., and Jones, J., 2010, Natural and Socioeconomical Drivers of Land Use Change in West Central Florida and Regional Climate Simulations Comparing Actual and Extreme Agriculture to Urban Conversion Scenarios [poster]. thunder.abe.ufl. edu/JLH_SECC_May2010_poster.pdf [accessed September 12, 2011]

Janicki, A., Pribble, R., Janicki, S., and Winowitch, M., 2001, An Analysis of Long-Term Trends in Tampa Bay Water Quality. Contract report prepared for Tampa Bay Estuary Program by Janicki Environmental, Inc., St.Petersburg, Florida. 401 p.

Kelly, K.L., 1998, A systems approach to identifying decisive information for sustainable development: European Journal of Operational Research, v. 109, p. 452-464, doi:10.1016/S0377-2217(98)00070-8.

Lawton, J.H., Bignell, D.E., Bolton, B., Bloemers, G.F., Eggleton, P., Hammond, P.M., Hodda, M., Holt, R.D., Larsen, T.B., Mawdsley,
N.A., Stork, N.E., Srivastava, D.S., and Watt, A.D., 1998, Biodiversity inventories, indicator taxa and effects of habitat modification in tropical forest: Nature, v. 391, p. 72-76, doi: $10.1038 / 34166$.

Lundin, M., 1999, Assessment of the Environmental Sustainability of Urban Water Systems: Göteborg, Sweden, Department of Technical Environmental Planning, Chalmers University of Technology, $55 \mathrm{p}$.

McCartney, M.P., and Houghton-Carr, H.A., 2009, Working Wetland Potential: An index to guide the sustainable development of African wetlands: Natural Resources Forum, v. 33, p. 99-110, doi:10.1111/ j.1477-8947.2009.01214.x.

Meadows, D., 1998, Indicators and Information Systems for Sustainable Development: A Report to the Balaton Group: Hartland Four Corners, Vermont, The Sustainability Institute, 78 p.

Mitchell, G., May, A., and McDonald, A., 1995, PICABUE: A methodological framework for the development of indicators of sustainable development: International Journal of Sustainable Development and World Ecology, v. 2, p. 104-123, doi:10.1080/ 13504509509469893.

North, L.A., van Beynen, P.E., and Parise, M., 2009, Interregional comparison of karst disturbance: West-central Florida and southeast Italy: Journal of Environmental Management, v. 9, no. 5, p. 1770-1781, doi:10.1016/j.jenvman.2008.11.018.

OECD, 1993, OECD Core Set of Indicators for Environmental Performance Reviews. A Synthesis Report by the Group on the State of the Environment: Paris, Organization for Economic Development and Co-operation, Environmental Monographs 83, 39 p.

Prescott-Allen, R., 2001, The Wellbeing of Nations: A Country-byCountry Index of Quality of Life and the Environment: Washington, D.C., Island Press, $342 \mathrm{p}$.

Rao, N.H., and Rogers, P.P., 2006, Assessment of agricultural sustainability: Current Science, v. 91, no. 4, p. 439-448.

Ronchi, E., Federico, A., and Musmeci, F., 2002, A system oriented integrated indicator for sustainable development in Italy. Ecological Indicators, v. 2, p. 197-210, doi:10.1016/S1470-160X(02)00045-6.

Shi, C., Hutchinson, S.M., and Xu, S., 2004, Evaluation of coastal zone sustainability: an integrated approach applied in Shanghai Municipality and Chong Ming Island: Journal of Environmental Management, v. 71, no. 4, p. 335-344, doi:10.1016/j.jenvman.2004.03.009.

Stankey, D.L., 1982, Soil survey of Pasco County: Florida: US Department of Agriculture, Soil Conservation Service, soil survey number $50,231 \mathrm{p}$.

Sullivan, C.A., Meigh, J.R., Giacomello, A.M., Fediw, T., Lawrence, P., Samad, M., Mlote, S., Hutton, C., Allan, J.A., Schulze, R.E., Dlamini, D.J.M., Cosgrove, W., Delli Priscolli, J., Gleick, P., Smout, I., Cobbing, J., Calow, R., Hunt, C., Hussain, A., Acreman, M.C., King, J., Malomo, S., Tate, E.L., O’Regan, D., Milner, S., and Steyl, I., 2003, The water poverty index: Development and application at the community scale: Natural Resources Forum, v. 27, p. 189-199, doi:10.1111/1477-8947.00054.

Sunkar, A., 2008, Sustainability in karst resources management: The case of the Gunung Sewu in Java. [PhD thesis]: University of Auckland, $240 \mathrm{p}$.

SWFWMD, 2001, Five-Year Land Acquisition Plan, 2001: Brooksville, Florida, Southwest Florida Water Management District.

SWFWMD, 2003, 2001 Estimated Water Use in the Southwest Florida Water Management District: Brooksville, Florida, Southwest Florida Water Management District, $160 \mathrm{p}$.

SWFWMD, 2004a, 2002 Estimated Water Use in the Southwest Florida Water Management District: Brooksville, Florida, Southwest Florida Water Management District, $179 \mathrm{p}$.

SWFWMD, 2004b, Estimated Water Use 1998-2009, Summary Report: Brooksville, Florida, Southwest Florida Water Management District, $5 \mathrm{p}$.

SWFWMD, 2009, 2007 Estimated Water Use in the Southwest Florida Water Management District: Brooksville, Florida, Southwest Florida Water Management District, 246 p.

SWFWMD, 2011a, 2009 Estimated Water Use in the Southwest Florida Water Management District: Brooksville, Florida, Southwest Florida Water Management District, 236 p.

SWFWMD, 2011b, Consolidated Annual Report, March 1, 2011: Brooksville, Florida, Southwest Florida Water Management District, $281 \mathrm{p}$. 
Tihansky, A.B., and Knochenmus, L.A., 2001, Karst features and hydrology in west-central Florida-A Field Perspective, in $\mathrm{Ku}-$ niansky, E.L., ed., United States Geological Survey Karst Interest Group Proceedings, St. Petersburg, Florida, February 13-16, 2001: U.S. Geological Survey, Water-Resources Investigation Report 014011, p. 198-211.

United Nations Development Program, 2003, Human Development Report 2003. Millennium Development Goals: A compact among nations to end human poverty: New York, Oxford University Press, $367 \mathrm{p}$.

United Nations General Assembly, 2005, 2005 World Summit Outcome, Resolution A/60/1, adopted by the General Assembly on 15 September 2005, http://unpan1.un.org/intradoc/groups/public/documents/ un/unpan021752.pdf [accessed February 2, 2009].

Urich, P.B., Day, M.J., and Lynagh, F., 2001, Policy and practice in karst landscape protection: Bohol, the Philippines: The Geographical Journal, v. 167, no. 4, p. 305-323, doi:10.1111/1475-4959.00028.

US Department of Agriculture, 1999, 1997 Census of Agriculture, State Level Data, Florida State and County Data, http://www.agcensus. usda.gov/Publications/1997/Vol_1_National,_State_and_County_Tables/ Florida/index.asp. [accessed September 13, 2011]

US Department of Agriculture, 2009, 2007 Census of Agriculture, State Level Data, http://www.agcensus.usda.gov/Publications/2007/ Full_Report/Volume_1,_Chapter_2_US_State_Level/usv1.pdf. [accessed September 15, 2011]
US EPA, 2008, U.S. EPA's 2008 Report on the Environment (Final Report): Washington, D.C., U.S. Environmental Protection Agency, EPA/600/R-07/045F, 344 p.

van Beynen, P.E., and Townsend, K.M., 2005, A disturbance index for karst environments: Environmental Management, v. 36, no. 1, p. 101-116, doi:10.1007/s00267-004-0265-9.

van Beynen, P.E., Feliciano, N., North, L., and Townsend, K., 2007, Application of the Karst Disturbance Index in Hillsborough County, Florida: Environmental Management, v. 39, p. 261-277, doi:10.1007/s00267-005-0393-x.

van Dijk, M.P., and Zhang M., 2005, Sustainability indices as a tool for urban managers, evidence from four medium-sized Chinese cities: Environmental Impact Assessment Review, v. 25, p. 667-688, doi:10.1016/j.eiar.2004.10.001.

Wackernagel, M., and Rees, W.E., 1996, Our Ecological Footprint: Reducing Human Impact on the Earth: Gabriola Island, B.C., Canada, New Society Publishers, 176 p.

World Commission on Environment and Development, 1987, Our Common Future: Oxford, Oxford University Press, 400 p.

World Economic Forum, 2002, 2002 Environmental Sustainability Index: An Initiative of the Global Leaders of Tomorrow Environment Task Force, World Economic Forum: New Haven, Connecticut, Yale Center for Environmental Law and Policy; and New York, Center for International Earth Science Information Network, Columbia University, 297 p., http://sedac.ciesin.columbia.edu/es/esi/ESI2002_ 21MAR02tot.pdf. [accessed September 13, 2011] 